\title{
FOSSIL AND NON-FOSSIL SOURCES OF DIFFERENT CARBONACEOUS FRACTIONS IN FINE AND COARSE PARTICLES BY RADIOCARBON MEASUREMENT
}

\author{
Y L Zhang ${ }^{1,2,3} \bullet$ P Zotter $^{2} \cdot$ N Perron ${ }^{2,4} \bullet$ A S H Prévôt ${ }^{2} \cdot$ L Wacker $^{5} \bullet$ S Szidat ${ }^{1,3,6}$
}

ABSTRACT. Radiocarbon offers a unique possibility for unambiguous source apportionment of carbonaceous particles due to a direct distinction of non-fossil and fossil carbon. In this work, particulate matter of different size fractions was collected at 4 sites in Switzerland to examine whether fine and coarse carbonaceous particles exhibit different fossil and contemporary sources. Elemental carbon (EC) and organic carbon (OC) as well as water-soluble OC (WSOC) and water-insoluble OC (WINSOC) were separated and determined for subsequent ${ }^{14} \mathrm{C}$ measurement. In general, both fossil and non-fossil fractions in $\mathrm{OC}$ and $\mathrm{EC}$ were found more abundant in the fine than in the coarse mode. However, a substantial fraction $(\sim 20 \pm 5 \%)$ of fossil EC was found in coarse particles, which could be attributed to traffic-induced non-exhaust emissions. The contribution of biomass burning to coarse-mode EC in winter was relatively high, which is likely associated to the coating of EC with organic and/or inorganic substances emitted from intensive wood burning. Further, fossil OC (i.e. from vehicle emissions) was found to be smaller than non-fossil OC due to the presence of primary biogenic OC and/or growing in size of wood-burning OC particles during aging processes. ${ }^{14} \mathrm{C}$ content in WSOC indicated that the second organic carbon rather stems from non-fossil precursors for all samples. Interestingly, both fossil and non-fossil WINSOC concentrations were found to be higher in fine particles than in coarse particles in winter, which is likely due to primary wood burning emissions and/or secondary formation of WINSOC.

\section{INTRODUCTION}

Carbonaceous particles, which significantly contribute to the atmospheric particulate matter (PM), are of worldwide concern due to their effects on climate, human health, and visibility (Pöschl 2005; Highwood and Kinnersley 2006; Jimenez et al. 2009). These particles vary in size with a mass median aerodynamic diameter from $<0.01$ to $>10 \mu \mathrm{m}$. They can be classified into fine and coarse fractions. Fine particles are defined as particulate matter with an aerodynamic diameter smaller than $2.5 \mu \mathrm{m}$ (i.e. $\mathrm{PM}_{2.5}$ ) and sometimes even smaller than $1 \mu \mathrm{m}$ (i.e. $\mathrm{PM}_{1}$ ) (Pöschl 2005), and coarse particles are defined as particles with a diameter larger than the fine fraction, but $<10 \mu \mathrm{m}$. The concentration of coarse particles is obtained by subtracting $\mathrm{PM}_{1}$ or $\mathrm{PM}_{2.5}$ from the total $\mathrm{PM}$ fraction with a diameter smaller than $10 \mu \mathrm{m}$ (i.e. $\mathrm{PM}_{10}$ ). Fine and coarse particles have different sources, chemical compositions, and lifetimes in the atmosphere. Based on epidemiological and toxicological studies (Nel 2005; Chang et al. 2011), health impacts of fine particles in air are more adverse than coarse particles because they can penetrate deeper in the human respiratory system. Consequently, understanding their sources and chemical compositions of both fine and coarse particles is highly important to establish separate regulations to control their emissions (Barmpadimos et al. 2012).

Total carbon (TC) is conventionally and operationally divided into 2 subfractions: non-absorptive and weakly refractory organic compounds of multifunctional carbon (organic carbon, OC); and optically absorptive and strongly refractory carbon content of graphitic-like material (elemental carbon, EC, which is also designated as black carbon, BC) (Castro et al. 1999; Pöschl 2005). EC derives exclusively from incomplete combustion of fossil fuels or biomass. OC can be emitted directly as

\footnotetext{
${ }^{1}$ Department of Chemistry and Biochemistry, University of Bern, Bern, Switzerland.

${ }^{2}$ Paul Scherrer Institute (PSI), Villigen, Switzerland.

${ }^{3}$ Oeschger Centre for Climate Change Research, University of Bern, Bern, Switzerland.

${ }^{4}$ Now at: Division of Nuclear Physics, Lund University, 22100 Lund, Sweden.

${ }^{5}$ Laboratory of Ion Beam Physics, ETH Hönggerberg, Zürich, Switzerland.

${ }^{6}$ Corresponding author. Email: szidat@iac.unibe.ch.
} 


\section{YL Zhang et al.}

primary organic carbon (POC) from biogenic emissions, wood burning, and fossil fuel combustion or can be formed by the oxidation of co-emitted volatile organic compounds and subsequent condensation as secondary organic carbon (SOC) (Pöschl 2005; Hallquist et al. 2009). Radiocarbon measurement of TC in the atmospheric particulate matter enables a direct distinction between the fossil and non-fossil sources (Currie 2000; Hodzic et al. 2010). Biomass burning is very important in winter in Switzerland (Lanz et al. 2010) but is difficult to separate from other non-fossil emissions based on ${ }^{14} \mathrm{C}$ measurement of TC alone. Recent works have attempted to measure ${ }^{14} \mathrm{C}$ in $\mathrm{OC}$ and $\mathrm{EC}$ separately (Szidat et al. 2009; Zhang et al. 2012), which allows a direct discrimination of the contributions from biomass and fossil fuel burning to $\mathrm{EC}$ and also enables a distinction of biogenic from biomass-burning sources of OC under certain conditions (Szidat et al. 2006). The challenge of ${ }^{14} \mathrm{C}$ measurement of $\mathrm{OC}$ and $\mathrm{EC}$ lies in the chemical separation of both, which is a prerequisite for unbiased source apportionment. A recent laboratory intercomparison revealed that especially the isolation of EC may be biased when using inappropriate methods (Szidat et al. 2013). To get more information about different fossil and non-fossil sources of $\mathrm{OC},{ }^{14} \mathrm{C}$ measurements were carried out on the aerosol water-soluble OC (WSOC) and/or water-insoluble OC (WINSOC) fractions (Szidat et al. 2004a; Weber et al. 2007; Wozniak et al. 2012) since WINSOC better represents primary organic carbon (POC), whereas WSOC is a proxy for secondary organic carbon and biomass-burning OC (Mayol-Bracero et al. 2002; Weber et al. 2007). However, only few studies have focused on the distribution of different sources of OC, WSOC, WINSOC, and EC in different PM size fractions. Furthermore, to our knowledge this is the first study presenting ${ }^{14} \mathrm{C}$ results for all the different carbon fractions simultaneously for fine- and coarse-mode particles.

In this paper, we present results of ${ }^{14} \mathrm{C}$-based source apportionment of OC and $\mathrm{EC}$ in fine and coarse particles conducted on filter samples collected at urban and rural sites in Switzerland. Furthermore, this study aims to examine whether contributions of fossil and non-fossil carbon in EC and OC vary for different PM size fractions. For this purpose, a newly developed method was applied, which allows isolation of $\mathrm{EC}$ for subsequent ${ }^{14} \mathrm{C}$ analysis with the minimized bias of both the positive and negative artifacts (i.e. pyrolysis of OC and premature combustion of EC) (Zhang et al. 2012). In addition, ${ }^{14} \mathrm{C}$-derived fossil and non-fossil sources were determined on both WSOC and WINSOC fractions for selected samples to better understand their origins and formation mechanisms. However, a general conclusion may not be feasible due to the small number of samples analyzed in this study. This pilot study aims to evaluate whether size-resolved source apportionment based on ${ }^{14} \mathrm{C}$ measurement could give more insights to current knowledge of the formation and evolution processes of carbonaceous particles and whether more intensive campaigns are necessary to get a clearer picture of size distributions of fossil and non-fossil fractions in carbonaceous particles.

\section{METHODS}

\section{Sampling}

The atmospheric samples were collected on prebaked quartz-fiber filters during various field campaigns using high-volume samplers with $\mathrm{PM}_{10}$ and $\mathrm{PM}_{1}$ or $\mathrm{PM}_{2.5}$ inlets as compiled in Table 1. As a $\mathrm{PM}_{1}$ inlet was not available for the sampling in Bern, $\mathrm{PM}_{2.5}$ was regarded as the fine fraction and compared with the $\mathrm{PM}_{1}$ results from the other 3 campaigns. We discuss in the following the composition of the fine particles $\left(\mathrm{PM}_{1}\right.$ and $\left.\mathrm{PM}_{2.5}\right)$ and coarse particles $\left(\mathrm{PM}_{10}-\mathrm{PM}_{2.5}\right.$ or $\left.\mathrm{PM}_{10}-\mathrm{PM}_{1}\right)$. The sampling duration was usually $24 \mathrm{hr}$ with the exception of the 2005 summer campaign in Moleno, where $48 \mathrm{hr}$ of sampling was carried out to get adequate amounts of carbon $(\sim 5 \mu \mathrm{g})$ on the filters for

${ }^{14} \mathrm{C}$ measurement. After sampling, the filters were individually wrapped in aluminum foils, packed in air-tight polyethylene bags, and stored at $-18{ }^{\circ} \mathrm{C}$ for later off-line analysis. 
Fossil \& Non-Fossil Sources of Different Carbonaceous Fractions

Table 1 Information of PM samples used in this study.

\begin{tabular}{|c|c|c|c|c|c|c|}
\hline $\begin{array}{l}\text { Sample } \\
\text { site }\end{array}$ & $\begin{array}{l}\text { Coordinates } \\
\text { and altitude }\end{array}$ & Site type & $\begin{array}{l}\text { Filter } \\
\text { code }\end{array}$ & $\begin{array}{l}\text { Sampling } \\
\text { day }\end{array}$ & Campaign & Size-cut \\
\hline Roveredo & $\begin{array}{l}46^{\circ} 14^{\prime} 18^{\prime \prime} \mathrm{N} \\
9^{\circ} 07^{\prime} 45^{\prime \prime} \mathrm{E} \\
298 \mathrm{~m} \text { asl }\end{array}$ & $\begin{array}{l}\text { Inside the village with } \sim 77 \% \\
\text { households using wood stoves in } \\
\text { winter (Szidat et al. 2007) }\end{array}$ & $\begin{array}{l}\text { ROV1 } \\
\text { ROV2 } \\
\text { ROV3 } \\
\text { ROV4 }\end{array}$ & $\begin{array}{l}\text { 23-Nov-05 } \\
\text { 6-Dec-05 } \\
\text { 8-Dec-05 } \\
\text { 14-Dec-05 }\end{array}$ & $\begin{array}{l}\text { ROV, } 2005 \\
\text { Winter }\end{array}$ & $\mathrm{PM}_{10} / \mathrm{PM}_{1}$ \\
\hline Zürich & $\begin{array}{l}47^{\circ} 22^{\prime} 39^{\prime \prime} \mathrm{N} \\
8^{\circ} 31^{\prime} 50^{\prime \prime \prime} \mathrm{E} \\
409 \mathrm{~m} \text { asl }\end{array}$ & $\begin{array}{l}\text { Urban background site without } \\
\text { immediate traffic exposure (Hue- } \\
\text { glin et al. 2005; Szidat et al. 2006) }\end{array}$ & $\begin{array}{l}\text { ZUR1 } \\
\text { ZUR2 } \\
\text { ZUR3 }\end{array}$ & $\begin{array}{l}\text { 9-Dec-08 } \\
11-\text { Dec-08 } \\
\text { 15-Dec-08 }\end{array}$ & $\begin{array}{l}\text { ZUR, } 2008 \\
\text { Winter }\end{array}$ & $\mathrm{PM}_{10} / \mathrm{PM}_{1}$ \\
\hline Moleno & $\begin{array}{l}46^{\circ} 16^{\prime} 46^{\prime \prime} \mathrm{N} \\
8^{\circ} 59^{\prime} 49^{\prime \prime} \mathrm{E} \\
254 \mathrm{~m} \text { asl }\end{array}$ & $\begin{array}{l}\text { In an Alpine valley right next to } \\
\text { the motorway outside villages } \\
\text { (Szidat et al. 2007) }\end{array}$ & $\begin{array}{l}\text { MOL1 } \\
\text { MOL2 }\end{array}$ & $\begin{array}{l}\text { 30-Jun-05 } \\
\text { 2-Jul-05 }\end{array}$ & $\begin{array}{l}\text { MOL, } 2006 \\
\text { Summer }\end{array}$ & $\mathrm{PM}_{10} / \mathrm{PM}_{1}$ \\
\hline Bern & $\begin{array}{l}46^{\circ} 57^{\prime} 04^{\prime \prime} \mathrm{N} \\
7^{\circ} 26^{\prime} 27^{\prime \prime} \mathrm{E} \\
536 \mathrm{~m} \text { asl }\end{array}$ & $\begin{array}{l}\text { Urban site with direct traffic expo- } \\
\text { sure (Hueglin et al. 2005) }\end{array}$ & $\begin{array}{l}\text { BER1 } \\
\text { BER2 }\end{array}$ & $\begin{array}{l}\text { 18-Jun-09 } \\
\text { 9-Sep-09 }\end{array}$ & $\begin{array}{l}\text { BER, } 2009 \\
\text { Summer }\end{array}$ & $\mathrm{PM}_{10} / \mathrm{PM}_{2.5}$ \\
\hline
\end{tabular}

\section{Separation of Carbonaceous Particle Fractions}

A thermo-optical OC/EC analyzer (Model4L, Sunset Laboratory Inc, USA) equipped with a nondispersive infrared (NDIR) detector was used to measure samples from Zürich and Bern applying a 4-step thermo-optical method (Swiss_4S) for separation of OC and EC for ${ }^{14} \mathrm{C}$ measurement (Zhang et al. 2012). Briefly, $\mathrm{OC}$ was isolated at $375^{\circ} \mathrm{C}$ within $150 \mathrm{~s}$ from untreated filters with more than $80 \%$ OC recovery, while water-insoluble OC (WINSOC) was separated under the same conditions after removal of water-soluble compounds by water extraction of the filter. Water-soluble OC (WSOC) was deduced from subtraction of TC and water-insoluble TC (WINSTC) based on mass and isotope-mass balancing. Isolation of $\mathrm{EC}$ was achieved by the oxidation of the remaining carbonaceous material at $760{ }^{\circ} \mathrm{C}$ within $150 \mathrm{~s}$ before complete $\mathrm{OC}$ removal during 2 intermediate steps. A different preparation system (Szidat et al. 2004a) was used for the samples from Roveredo and Moleno from the 2005/2006 campaign. The separation method was described in detail in Szidat et al. 92004a). Briefly, OC and WINSOC were isolated at $340{ }^{\circ} \mathrm{C}$ within $10 \mathrm{~min}$ from untreated and water-extracted samples, respectively. For EC isolation, water-extracted samples were heated for $4 \mathrm{hr}$ in air at $375{ }^{\circ} \mathrm{C}$ to eliminate $\mathrm{OC}$ and then combusted totally at $650{ }^{\circ} \mathrm{C}$. In a recent study, we showed that both methods reveal comparable ${ }^{14} \mathrm{C}$ results of OC and EC (Zhang et al. 2012); however, a correction of premature EC losses during the thermal treatment is necessary for ${ }^{14} \mathrm{C}$ measurement of EC, which was applied in this study according to the approach in Zhang et al. (2012).

\section{Source Apportionment OC and EC by ${ }^{14} \mathrm{C}$ Data}

${ }^{14} \mathrm{C}$ analysis of collected $\mathrm{CO}_{2}$ was performed off-line with the Mini Carbon Dating System (MICADAS) (Synal et al. 2007), which allows direct $\mathrm{CO}_{2}$ injection after dilution with $\mathrm{He}$ (Ruff et al. 2007; Wacker et al. 2013). All ${ }^{14} \mathrm{C}$ results are expressed as fraction of modern (Fm), i.e. the fraction of the ${ }^{14} \mathrm{C} /{ }^{12} \mathrm{C}$ ratio of the sample related to the isotopic ratio of the reference year 1950 (Stuiver and Polach 1977). This data was corrected for ${ }^{14} \mathrm{C}$ decay during the period between 1950 and the year of measurement. The Fm value for fossil sources is characterized by $\mathrm{Fm}=0$ due the extinction of ${ }^{14} \mathrm{C}$ with a half-life of $5370 \mathrm{yr}$. The Fm values of the contemporary carbon sources including biogenic and biomass burning ( $\mathrm{Fm}_{\text {bio }}$ and $\mathrm{Fm}_{\mathrm{bb}}$, respectively) are larger than the theoretical modern level of 1 due to the nuclear-bomb excess in the 1950s and 1960s (Szidat et al. 2006; Levin et al. 2010), which are esti- 


\section{YL Zhang et al.}

mated to be $\mathrm{Fm}_{\mathrm{bb}}=1.116 \pm 0.05$ and $1.133 \pm 0.05$, and $\mathrm{Fm}_{\mathrm{bio}}=1.045 \pm 0.015$ and $1.055 \pm 0.015$ for $2008 / 2009$ and 2005/2006, respectively. The value of $\mathrm{Fm}_{\mathrm{bb}}$ was estimated by a tree-growth model (Mohn et al. 2008) including 10-, 20-, 40-, 70-, and 85-yr-old trees with weights of 0.2, 0.2, 0.4, 0.1, and 0.1 , respectively, and the value of $\mathrm{Fm}_{\text {bio }}$ was taken from the long-term series of ${ }^{14} \mathrm{CO}_{2}$ measurements at the Schauinsland station (Levin et al. 2010). The Fm of non-fossil $\left(\mathrm{Fm}_{\mathrm{nf}}\right)$ EC equals $\mathrm{Fm}_{\mathrm{bb}}$, given that biomass burning is the only non-fossil source of $\mathrm{EC}$. The $\mathrm{Fm}_{\mathrm{nf}}$ of OC was determined as the average of $\mathrm{Fm}_{\mathrm{bb}}$ and $\mathrm{Fm}_{\mathrm{bio}}$ assuming that non-fossil $\mathrm{OC}$ originates equally from biogenic emissions and biomass burning. In addition, Fm(EC) reported here has been corrected for the premature EC loss during the OC removal step, with an approach described in Zhang et al. (2012). The typical uncertainties of source apportionment results arise from analytical uncertainties, the variability of reference $\mathrm{Fm}_{\mathrm{nf}}$ values, and recoveries of different carbon fractions approximately amounted to $\pm 15 \%, \pm 20 \%, \pm 20 \%$, and $\pm 15 \%$ for fossil EC, biomass burning EC, fossil OC (both WSOC and WINSOC fractions), and non-fossil OC (both WSOC and WINSOC fractions), respectively.

\section{RESULTS}

\section{EC and OC Concentrations}

Concentrations of the carbonaceous particles (EC and $\mathrm{OC}$ ) are presented in Table 2. The overall average EC and $\mathrm{OC}$ concentrations in the fine fraction were 2.1 and $5.4 \mu \mathrm{g} / \mathrm{m}^{3}$ and those in $\mathrm{PM}_{10}$ were 2.6 and $7.7 \mu \mathrm{g} / \mathrm{m}^{3}$, respectively. The carbonaceous aerosol concentrations for the winter campaign in Roveredo were notably high, which was associated with the accumulation of the local aerosol emissions due to strong inversion conditions during the sampling periods (Szidat et al. 2007). On average, $73 \%, 81 \%$, and $70 \%$ of TC, EC, and OC, respectively, measured in $\mathrm{PM}_{10}$ were present in the fine mode. The enrichment in fine particles is more pronounced for EC than for OC. The EC emission fraction is higher in the fine mode because it mainly originates from traffic, whereas OC can have contributions of primary coarse particles such as biological material (e.g. bacteria, pollen, and vegetative detritus), even in winter (Szidat et al. 2006). A large fraction of OC was found in the diameters between 2.5 and $4.0 \mu \mathrm{m}$, which was associated with species with a crustal origin (Jaffrezo et al. 2005). The ratio of EC and TC (EC/TC) was slightly higher in the fine fraction than in $\mathrm{PM}_{10}$. This result is consistent with a recent study carried out at the Gosan $\mathrm{ABC}$ superstation (Lim et al. 2012). The distribution patterns of EC among particle sizes suggest substantially larger anthropogenic emissions (i.e. vehicle exhaust and wood burning) in fine carbonaceous particles. Among the 4 sites, the highest EC/TC ratios in both fine and coarse particles were observed at Moleno in summer, the site adjacent to the motorways, most likely due to comparably larger primary emissions from direct vehicular emission. Both vehicle tailpipe exhaust (mostly fine) and non-exhaust (mostly coarse) may contain carbonaceous particles. The large EC/TC ratios at the traffic site in the fine mode imply primary traffic-related exhaust, whereas the large ratios in the coarse mode may imply an important contributor to EC particles from the vehicle non-exhaust emissions such as wear on tires and brakes and road surface wear from abrasion and/or resuspension. Moreover, a major fraction of the $\mathrm{OC}$ at Zürich and Bern was water-soluble (WSOC/OC $=65 \%$, ranging from $59 \%$ to $82 \%$ ), consistently with a higher WSOC loading in the fine fraction compared to $\mathrm{PM}_{10}$, indicating a considerably high SOC contribution in Bern and high SOC and/or wood burning contribution in Zürich.

\section{Results of ${ }^{14} \mathrm{C}$ Analysis}

Table 2 shows the fraction of modern (Fm) of EC, OC, WSOC, and WINSOC. In the following, the $\mathrm{Fm}$ values are given as the arithmetic average and the associated standard deviation of the Fm values of all the filters for the individual campaigns. In winter, $\mathrm{Fm}(\mathrm{EC})$ and $\mathrm{Fm}(\mathrm{OC})$ for $\mathrm{PM}_{10}$ were much 
Table 2 OC, EC concentrations $\left(\mu \mathrm{g} / \mathrm{m}^{3}\right)$ and WSOC/OC, EC/TC ratios as well as fraction of modern $(\mathrm{Fm})$ of OC, EC, WSOC, and WINSOC. Typical uncertainties are 15\% for EC, $7 \%$ for OC, $15 \%$ for EC/TC, 10\% for WSOC/OC, 10\% for Fm(EC), 5\% for Fm(OC), 10\% for Fm(WSOC) and 5\% for Fm(WINSOC). "n.a." means "not analyzed."

\begin{tabular}{|c|c|c|c|c|c|c|c|c|c|}
\hline $\begin{array}{l}\text { Filter } \\
\text { code }\end{array}$ & $\begin{array}{l}\text { Size } \\
\text { cut }\end{array}$ & $\mathrm{EC}$ & $\mathrm{OC}$ & $\mathrm{EC} / \mathrm{TC}$ & WSOC/OC & $\begin{array}{l}\text { Fm } \\
(\mathrm{EC})\end{array}$ & $\begin{array}{l}\text { Fm } \\
(\mathrm{OC})\end{array}$ & $\begin{array}{l}\text { Fm } \\
\text { (WSOC) }\end{array}$ & $\begin{array}{l}\text { Fm } \\
\text { (WINSOC) }\end{array}$ \\
\hline \multicolumn{10}{|c|}{ Roveredo, winter, 2005} \\
\hline \multirow[t]{3}{*}{ ROV1 } & $\mathrm{PM}_{1}$ & 3.3 & 9.2 & 0.26 & n.a. & 0.65 & 1.01 & n.a. & n.a. \\
\hline & $\mathrm{PM}_{1-10}$ & 0.4 & 4.3 & 0.09 & & 0.35 & 0.93 & & \\
\hline & $\mathrm{PM}_{10}$ & 3.7 & 13.5 & 0.22 & & 0.61 & 0.99 & & \\
\hline \multirow[t]{3}{*}{ ROV2 } & $\mathrm{PM}_{1}$ & 1.8 & 6.3 & 0.22 & & 0.67 & 1.04 & & \\
\hline & $\mathrm{PM}_{1-10}$ & 0.6 & 1.4 & 0.30 & & 0.36 & 1.23 & & \\
\hline & $\mathrm{PM}_{10}$ & 2.4 & 7.7 & 0.24 & & 0.59 & 1.08 & & \\
\hline \multirow[t]{3}{*}{ ROV3 } & $\mathrm{PM}_{1}$ & 3.4 & 11.5 & 0.23 & & 0.92 & 1.09 & & \\
\hline & $\mathrm{PM}_{1-10}$ & 0.9 & 4.1 & 0.18 & & 0.77 & 1.21 & & \\
\hline & $\mathrm{PM}_{10}$ & 4.3 & 15.7 & 0.21 & & 0.89 & 1.12 & & \\
\hline \multirow[t]{3}{*}{ ROV4 } & $\mathrm{PM}_{1}$ & 2.5 & 9.9 & 0.20 & & 0.72 & 1.07 & & \\
\hline & $\mathrm{PM}_{1-10}$ & 0.8 & 4.2 & 0.16 & & 0.57 & 1.03 & & \\
\hline & $\mathrm{PM}_{10}$ & 3.3 & 14.1 & 0.19 & & 0.68 & 1.06 & & \\
\hline \multicolumn{10}{|c|}{ Zürich, winter, 2008} \\
\hline \multirow{3}{*}{ ZUR1 } & $\mathrm{PM}_{1}$ & 1.5 & 3.2 & 0.31 & 0.61 & 0.47 & 0.79 & 0.84 & 0.71 \\
\hline & $\mathrm{PM}_{1-10}$ & 0.2 & 1.5 & 0.10 & 0.58 & 0.32 & 1.05 & 1.26 & 0.70 \\
\hline & $\mathrm{PM}_{10}$ & 1.6 & 4.8 & 0.26 & 0.60 & 0.46 & 0.87 & 0.98 & 0.71 \\
\hline \multirow[t]{3}{*}{ ZUR2 } & $\mathrm{PM}_{1}$ & 1.1 & 2.2 & 0.32 & 0.65 & 0.27 & 0.59 & 0.52 & 0.73 \\
\hline & $\mathrm{PM}_{1-10}$ & 0.2 & 0.8 & 0.17 & 0.42 & 0.50 & 0.76 & 0.79 & 0.54 \\
\hline & $\mathrm{PM}_{10}$ & 1.2 & 3.1 & 0.29 & 0.59 & 0.30 & 0.64 & 0.62 & 0.66 \\
\hline \multirow[t]{3}{*}{ ZUR3 } & $\mathrm{PM}_{1}$ & 2.4 & 4.0 & 0.38 & 0.63 & 0.42 & 0.75 & 0.79 & 0.69 \\
\hline & $\mathrm{PM}_{1-10}$ & 0.5 & 2.3 & 0.19 & 0.55 & 0.36 & 0.91 & 0.95 & 0.80 \\
\hline & $\mathrm{PM}_{10}$ & 2.9 & 6.2 & 0.32 & 0.60 & 0.40 & 0.81 & 0.86 & 0.74 \\
\hline \multicolumn{10}{|c|}{ Moleno, summer, 2006} \\
\hline \multirow[t]{3}{*}{ MOL1 } & $\mathrm{PM}_{1}$ & 1.1 & 1.0 & 0.52 & n.a. & 0.06 & 0.67 & n.a. & n.a. \\
\hline & $\mathrm{PM}_{1-10}$ & 0.3 & 0.5 & 0.38 & & 0.13 & 1.13 & & \\
\hline & $\mathrm{PM}_{10}$ & 1.5 & 1.6 & 0.48 & & 0.08 & 0.82 & & \\
\hline \multirow[t]{3}{*}{ MOL2 } & $\mathrm{PM}_{1}$ & 1.4 & 1.6 & 0.46 & & 0.09 & 0.66 & & \\
\hline & $\mathrm{PM}_{1-10}$ & 0.3 & 0.6 & 0.32 & & 0.17 & 0.90 & & \\
\hline & $\mathrm{PM}_{10}$ & 1.7 & 2.3 & 0.42 & & 0.10 & 0.73 & & \\
\hline \multicolumn{10}{|c|}{ Bern, summer, 2009} \\
\hline \multirow[t]{3}{*}{ BER1 } & $\mathrm{PM}_{2.5}$ & 3.0 & 4.3 & 0.42 & 0.67 & 0.06 & 0.69 & 0.73 & 0.56 \\
\hline & $\mathrm{PM}_{2.5-10}$ & 0.6 & 3.6 & 0.14 & 0.58 & 0.27 & 0.68 & 0.70 & 0.66 \\
\hline & $\mathrm{PM}_{10}$ & 3.6 & 7.8 & 0.31 & 0.63 & 0.09 & 0.69 & 0.72 & 0.61 \\
\hline \multirow[t]{3}{*}{ BER2 } & $\mathrm{PM}_{2.5}$ & 1.6 & 5.7 & 0.22 & 0.82 & 0.09 & 0.72 & 0.76 & 0.53 \\
\hline & $\mathrm{PM}_{2.5-10}$ & 0.7 & 2.5 & 0.22 & 0.48 & 0.15 & 0.67 & 0.75 & 0.60 \\
\hline & $\mathrm{PM}_{10}$ & 2.3 & 8.1 & 0.22 & 0.72 & 0.11 & 0.70 & 0.75 & 0.57 \\
\hline
\end{tabular}

higher in Roveredo [i.e. $0.70 \pm 0.10$ for $\mathrm{Fm}(\mathrm{EC}) ; 1.06 \pm 0.04$ for $\mathrm{Fm}(\mathrm{OC})$ ] than those in Zürich [i.e. $0.39 \pm 0.05$ for $\mathrm{Fm}(\mathrm{EC}) ; 0.77 \pm 0.07$ for $\mathrm{Fm}(\mathrm{OC})$ ], showing a higher contribution of non-fossil sources to EC and OC at the rural site, which is attributed to the influence of intensive wood-burning and strong inversion conditions in winter. This observation is consistent with an earlier study of wood-burning emissions from residential heating in Alpine valleys during winter (Szidat et al. 2007; Sandradewi et al. 2008; Lanz et al. 2010). In summer, the Fm(EC) values for $\mathrm{PM}_{10}$ at Moleno (i.e. $0.09 \pm 0.05$ ) and Bern (i.e. $0.06 \pm 0.03$ ) were lower than those in winter at Roveredo and Zürich by a factor of 3 15, implying EC nearly solely originated from fossil-fuel sources such as trafficrelated emissions during the sampling periods. Fm(EC) values were always lower than correspond- 


\section{YL Zhang et al.}

ing $\mathrm{Fm}(\mathrm{OC})$ determinations, regardless of season, site, and size fraction, suggesting a larger fossil contribution to EC. In terms of different size fractions, Fm(EC) tended to be slightly higher in $\mathrm{PM}_{10}$ compared to $\mathrm{PM}_{1}$ in winter at Zürich and Roveredo, while Fm(EC) in summer at Bern and Moleno exhibited an opposite trend. Due to the measurement uncertainties, however, a clear size trend of Fm(EC) remains unproven. Concerning Fm(OC), no significant difference are found in Roveredo and Bern, whereas the non-fossil contribution is higher in $\mathrm{PM}_{10}$ compared to $\mathrm{PM}_{1}$ at Moleno and Zürich. The differences are not significant, however. In addition, OC was subdivided to WSOC and WINSOC for ${ }^{14} \mathrm{C}$ analysis on samples collected at Zürich and Bern (see Table 2). Both the Fm values of the WSOC and WINSOC fractions were lower at Bern than those at Zürich, suggesting a substantially higher fossil contribution of primary and secondary OC at Bern. WSOC was generally enriched in ${ }^{14} \mathrm{C}$ by $15-40 \%$ relative to WINSOC in all size fractions. Previous studies also found significant fossil contributions for WINSOC compared to WSOC (Weber et al. 2007; Szidat et al. 2009; Kirillova et al. 2010; Wozniak et al. 2013; Zhang et al. 2012); thus, contemporary OC is considerably more water-soluble than fossil-originated OC across all size fractions. No trend was found in summer at Bern for the WSOC fraction, whereas WINSOC was more modern in the coarse particles than in the fine fraction. However, Fm values for WSOC were higher in the coarse than in the fine fraction at Zürich in winter. This suggests a different origin and/or process of WSOC and WINSOC for both sites, which will discussed further below.

\section{Source Apportionment of EC}

Figure 1 shows an average apportionment of $\mathrm{EC}$ into fossil $\left(\mathrm{EC}_{\mathrm{f}}\right)$ and biomass-burning sources $\left(\mathrm{EC}_{\mathrm{bb}}\right)$ in both the fine and coarse mode. Overall, $\mathrm{EC}$ was dominated by fossil sources except for the samples from Roveredo. During the winter in Zürich, the absolute $\mathrm{EC}_{\mathrm{f}}$ amount $\left(\sim 1.24 \mu \mathrm{g} / \mathrm{m}^{3}\right)$ for $\mathrm{PM}_{10}$ in 2008 from this study was lower by a factor of 2 than reported values $\left(\sim 2.6 \mu \mathrm{g} / \mathrm{m}^{3}\right)$ in 2003 , but the contribution of $\mathrm{EC}_{\mathrm{f}}$ to total $\mathrm{EC}$ was still identical within the uncertainty between the $2 \mathrm{cam}$ paigns (i.e. $64 \pm 6 \%$ and $65 \pm 7 \%$ for 2008 and 2003, respectively) (Szidat et al. 2006; Zhang et al. 2012). In Roveredo, biomass-burning $\mathrm{EC}$ in $\mathrm{PM}_{1}$ was the dominant fraction of the total (measured in the $\mathrm{PM}_{10}$ size fraction) $\mathrm{EC}$. In summer, the $\mathrm{PM}_{1} \mathrm{EC}_{\mathrm{f}}$ accounted for $90 \pm 2 \%$ of the total $\mathrm{EC}$ at Bern and Moleno, indicating EC is predominantly stemming from road traffic. The high contribution of vehicular emissions to $\mathrm{EC}$ was also found in summer in Barcelona (Minguillon et al. 2011). $\mathrm{EC}_{\mathrm{f}}$ and $\mathrm{EC}_{\mathrm{bb}}$ in the fine size fraction contributed on average $80 \pm 5 \%$ and $73 \pm 14 \%$ to the total $\mathrm{EC}$ (in $\mathrm{PM}_{10}$ ) for all sites, respectively. This indicates that both biomass-burning and fossil EC are preferably enriched in the fine particle mode; however, the enrichment of biomass-burning EC in fine particles in summer is not as prominent as in winter due to measurement uncertainties and smaller biomass burning emissions. On the contrary, on average $20 \%$ of fossil EC was found in the coarse fraction for all sites. Fossil EC in the coarse mode is unlikely emitted directly from combustion sources such as traffic-related exhaust, as most of these exhaust particles are found in the fine size fractions (Lighty et al. 2000). Instead, fossil EC in the coarse mode is usually assumed to originate from resuspension of vehicle non-exhaust emissions from tire wear, brake wear, and road surface wear (Bukowiecki et al. 2010). Consequently, the contributions of the vehicle non-exhaust emissions to total EC in $\mathrm{PM}_{10}$ obtained were $7 \%, 12 \%, 18 \%$, and $18 \%$ at Roveredo, Zürich, Moleno, and Bern, respectively. Biomass burning was also found to be an important source to the coarse EC, with a contribution of $49 \%$ and $34 \%$ in winter at Roveredo and Zürich, whereas biomass-burning EC amounted to $12 \%$ and $19 \%$ in summer at Moleno and Bern. This observation implies that the fraction of directly emitted coarse biomass-burning EC is higher than for traffic. Another possible explanation is the higher likelihood of the biomass-burning particles growing to super-micron particles since the emitted particles are already larger than the ones from traffic. This may especially be very important in 
winter when the secondary inorganic contributions condensing on the particles are higher compared to summer, especially for ammonium nitrate (Lanz et al. 2010; Minguillon et al. 2012).

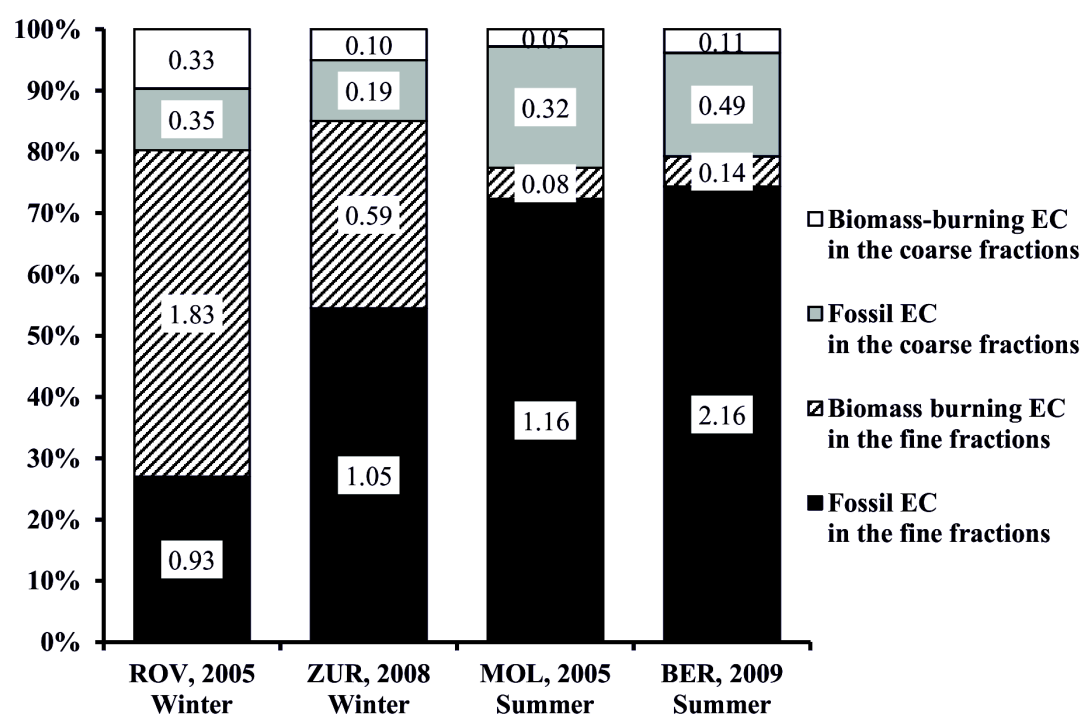

Figure 1 Average percentage and carbon concentration (in $\mu \mathrm{g} / \mathrm{m}^{3}$ ) of the different EC fractions determined with the ${ }^{14} \mathrm{C}$-based source apportionment model for the 4 campaigns in the different size fractions.

\section{Source Apportionment of OC}

OC was apportioned into fossil and non-fossil contributions for both fine and coarse fractions, as shown in Figure 2. In winter, fossil OC contributed $34 \pm 4 \%$ and $16 \pm 6 \%$ to OC in fine and coarse particles in Zürich, respectively, whereas in Roveredo the values were $6 \pm 3 \%$ and $4 \pm 2 \%$. This result is consistent with the expectation that fossil sources have a higher influence in Zürich, the largest city in Switzerland, due to the high vehicle emissions on the one hand and the large woodburning contribution in Roveredo, a small town in an alpine valley, on the other hand. A major fraction of both fossil and non-fossil OC was found in the fine fraction for all samples. However, this enrichment in the fine mode was often less pronounced for non-fossil OC compared to fossil OC, implying that fossil OC (i.e. from vehicle emissions) particles are smaller in diameter than non-fossil OC (i.e. biomass burning and biogenic emissions) particles. The occurrence of non-fossil OC in coarse particles can be attributed to aerosols from primary biogenic materials such as microorganisms, plant debris, and pollen. The mass determination of OC can even be affected by a few large particles, although primary coarse biogenic $\mathrm{OC}$ is limited in winter. More investigations are needed, but another explanation could be that OC particles emitted from intensive wood burning are growing larger after resuspension or during aging processes with high relative humidity. This effect is similar to the observation for wood-burning EC made above.

Total WINSOC was found to have a higher fossil contribution compared to WSOC (Figure 3), suggesting on the one hand that fossil OC is substantially less water soluble than non-fossil OC (i.e. biomass burning OC) and on the other hand that the main component of the extracted WSOC is from non-fossil precursors derived SOC or stems from incomplete combustion of biomass. The presence of fossil WSOC ( $\sim 25 \%$ and $\sim 30 \%$ of total WSOC at Zurich and Bern, respectively) in the samples 


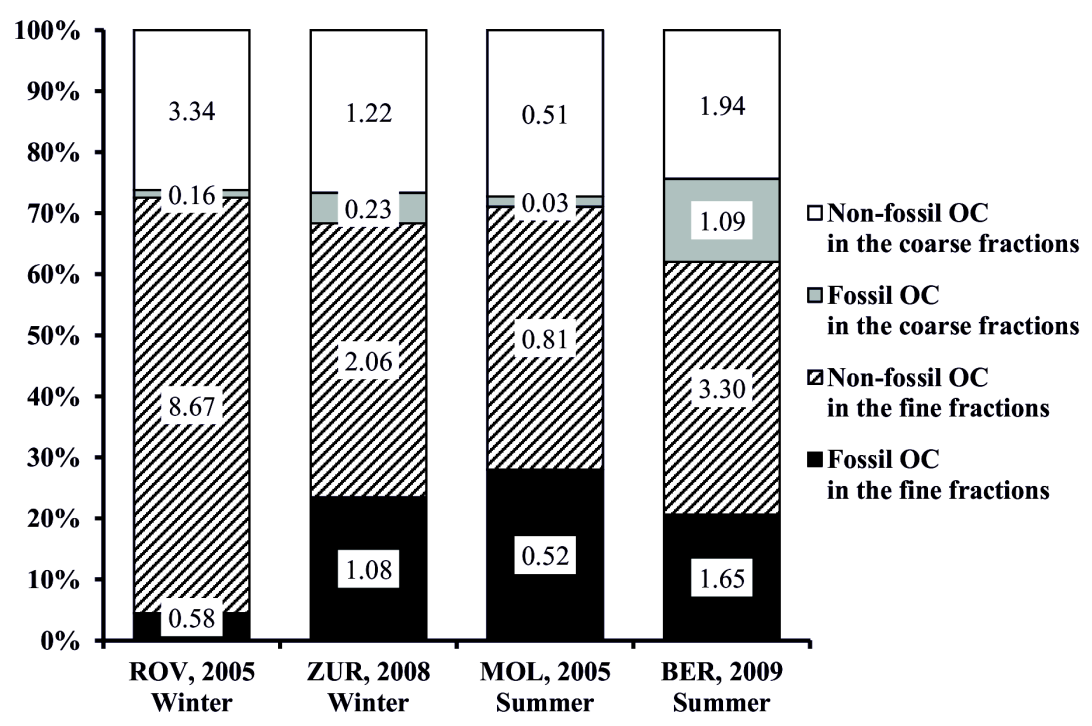

Figure 2 Average percentage and carbon concentration (in $\mu \mathrm{g} / \mathrm{m}^{3}$ ) determined with the ${ }^{14} \mathrm{C}$-based source apportionment model for the 4 campaigns in the different size fractions.

indicates a substantial contribution of SOC formed from VOCs emitted by fossil sources or aged primary OC particles from fossil fuel combustion to WSOC. Concerning the contributions of the different size fractions, it was found that non-fossil WSOC in the fine mode was the largest fraction of the total OC. However, in Zürich and Bern, fossil OC in the fine mode was more pronounced in WSOC than in WINSOC. In Zurich, only $\sim 5 \%$ fossil WSOC was present in the coarse fraction, indicating a major portion of fossil-derived SOC is in the fine fraction. On the contrary, a considerable portion (33\%) of fossil WSOC in summer was found in coarse particles in Bern, which points out that fossil SOC may partially condense on primary coarse particles from biogenic emissions. It is also noteworthy that non-fossil WINSOC was also higher in the fine fraction than in the coarse fraction in winter in Zürich. This may be attributed to primary wood burning OC emissions and/or the secondary formation of WINSOC. Sciare et al. (2011) found that a large fraction of WINSOC in the region of Paris during the winter time was most likely attributed to SOC, which originated from semivolatile primary organic carbon particles from wood burning and/or anthropogenic emissions. The secondary formation of water-insoluble SOC in Sciare et al. (2011) was explained by weak photochemical activity occurring during winter, leading to less oxidized (i.e. less water-soluble) SOC. However, such a size fraction-dependent behavior of WINSOC was not observed for Bern in summer, implying a primary origin of WINSOC. Further investigations are needed, but it could be hypothesized that SOC may be nearly solely composed of WSOC in summer, whereas SOC can be attributed to both WSOC and WINSOC during winter. Similarly, the significant secondary formation of WINSOC was also found in a semi-arid urban environment as reported in Favez et al. (2008).

Non-fossil OC from the summer samples was apportioned into biomass burning and biogenic sources applying an advanced model based on ${ }^{14} \mathrm{C}$ measurement of OC and an assumed EC/OC emission ratio from biomass burning as described in Szidat et al. (2006). On average, biogenic emissions accounted for approximately half and two thirds of non-fossil OC at Moleno and Bern, respectively. Unfortunately, this could not be applied for samples in winter, as wood burning was the overwhelming contribution of non-fossil OC. 

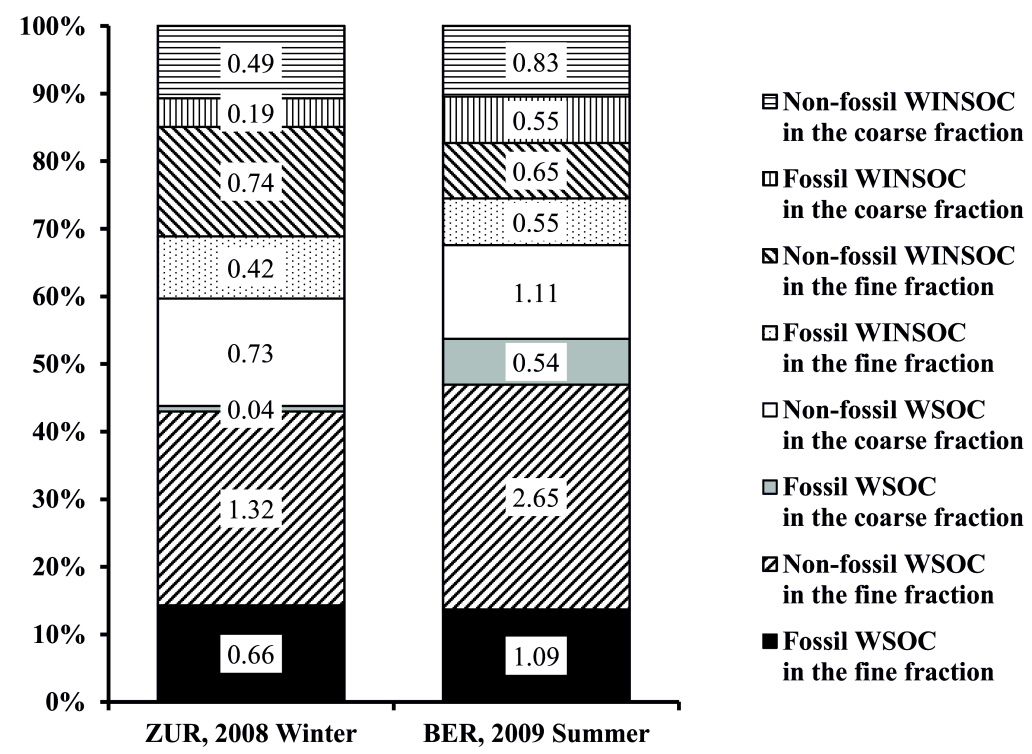

Figure 3 Average percentage and carbon concentration (in $\mu \mathrm{g} / \mathrm{m}^{3}$ ) of the different fractions for WINSOC and WSOC determined with the ${ }^{14} \mathrm{C}$-based source apportionment model for the 4 campaigns in the different size fractions.

\section{CONCLUSIONS}

${ }^{14} \mathrm{C}$-based source apportionment of carbonaceous particles was conducted for $\mathrm{EC}, \mathrm{OC}$, WSOC, and WINSOC in both the fine and coarse size fractions. Overall, OC was dominated by non-fossil sources, whereas EC was dominated by fossil emissions in both the fine and coarse mode for samples from all stations except for Roveredo, where intensive wood burning and inversion conditions occurred during the sampling period. Furthermore, both fossil and non-fossil fractions in OC and EC were found more abundant in the fine than in the coarse factions. Around $20 \%$ of fossil EC was observed in the coarse mode, which is most likely attributed to resuspension of abrasion of tire, break, and street wear. Biomass-burning EC was found to be an additional contributor to coarse EC in winter due to either direct coarse particle emissions or growth of fine EC with secondary organic and inorganic substances into the coarse diameter range. A substantial fraction of the non-fossil OC was also present in coarse particles, which is associated to primary biogenic OC (i.e. microorganisms, plant debris, and pollen) and to $\mathrm{OC}$ particles from wood burning that grow larger during aging processes. Further, OC was divided into WSOC and WINSOC for ${ }^{14} \mathrm{C}$ measurement. WSOC was found to have a higher non-fossil contribution than WINSOC, suggesting that non-fossil OC is more water soluble than fossil OC. However, fossil WSOC was enriched in the fine compared to the coarse size fraction for both Zürich and Bern. This enrichment was by a factor of 7 higher for winter in Zürich than for summer in Bern, which may be associated with the condensation of fossil-derived SOC on primary coarse particles in summer. For winter in Zürich, non-fossil WINSOC occurred rather in the fine mode, which is likely due to secondary formation of WINSOC or some insoluble carbon from primary wood burning emissions. From this and other studies (Favez et al. 2008; Sciare et al. 2011), it is reasonable to speculate that SOC can also be attributed to both WSOC and WINSOC, contrasting the idea SOC is mainly water soluble. Further measurements are needed to investigate the relative contributions of primary and secondary formation of both WINSOC and WSOC by measuring their ${ }^{14} \mathrm{C}$ and some organic tracers under different meteorological conditions. 


\section{Y L Zhang et al.}

\section{ACKNOWLEDGMENTS}

This work was supported by the Swiss Federal Office for the Environment (FOEN) and the Swiss Cantons of Graubünden and Ticino. We thank Dr Christoph Hüglin (EMPA) for providing particulate matter samples for Zürich and Bern.

\section{REFERENCES}

Barmpadimos I, Keller J, Oderbolz D, Hueglin C, Prevot ASH. 2012. One decade of parallel fine $\left(\mathrm{PM}_{2.5}\right)$ and coarse $\left(\mathrm{PM}_{10}-\mathrm{PM}_{2.5}\right)$ particulate matter measurements in Europe: trends and variability. Atmospheric Chemistry and Physics 12(7):3189-203.

Bukowiecki N, Lienemann P, Hill M, Furger M, Richard A, Amato F, Prevot ASH, Baltensperger U, Buchmann B, Gehrig R. 2010. PM10 emission factors for non-exhaust particles generated by road traffic in an urban street canyon and along a freeway in Switzerland. Atmospheric Environment 44(19):2330-40.

Castro LM, Pio CA, Harrison RM, Smith DJT. 1999. Carbonaceous aerosol in urban and rural European atmospheres: estimation of secondary organic carbon concentrations. Atmospheric Environment 33(17): 2771-81.

Chang HH, Peng RD, Dominici F. 2011. Estimating the acute health effects of coarse particulate matter accounting for exposure measurement error. Biostatistics 12(4):637-52.

Currie LA. 2000. Evolution and multidisciplinary frontiers of ${ }^{14} \mathrm{C}$ aerosol science. Radiocarbon $42(1): 115$ 26.

Favez O, Sciare J, Cachier H, Alfaro SC, Abdelwahab MM. 2008. Significant formation of water-insoluble secondary organic aerosols in semi-arid urban environment. Geophysical Research Letters 35(15): L15801.

Hallquist M, Wenger JC, Baltensperger U, Rudich Y, Simpson D, Claeys M, Dommen J, Donahue NM, George C, Goldstein AH. 2009. The formation, properties and impact of secondary organic aerosol: current and emerging issues. Atmospheric Chemistry and Physics 9(14):5155-236.

Highwood EJ, Kinnersley RP. 2006. When smoke gets in our eyes: the multiple impacts of atmospheric black carbon on climate, air quality and health. Environment International 32(4):560-6.

Hodzic A, Jimenez JL, Prévôt ASH, Szidat S, Fast JD, Madronich S. 2010. Can 3-D models explain the observed fractions of fossil and non-fossil carbon in and near Mexico City? Atmospheric Chemistry and Physics 10(22):10,997-11,016.

Hueglin C, Gehrig R, Baltensperger U, Gysel M, Monn C, Vonmont H. 2005. Chemical characterisation of PM2.5, PM10 and coarse particles at urban, near-city and rural sites in Switzerland. Atmospheric Environment 39(4):637-51.

Jaffrezo JL, Aymoz G, Cozic J. 2005. Size distribution of
EC and OC in the aerosol of Alpine valleys during summer and winter. Atmospheric Chemistry and Physics 5:2915-25.

Jimenez JL, Canagaratna MR, Donahue NM, Prevot ASH, Zhang Q, Kroll JH, DeCarlo PF, Allan JD, Coe $\mathrm{H}, \mathrm{Ng}$ NL, Aiken AC, Docherty KS, Ulbrich IM, Grieshop AP, Robinson AL, Duplissy J, Smith JD, Wilson KR, Lanz VA, Hueglin C, Sun YL, Tian J, Laaksonen A, Raatikainen T, Rautiainen J, Vaattovaara P, Ehn M, Kulmala M, Tomlinson JM, Collins DR, Cubison MJ, Dunlea EJ, Huffman JA, Onasch TB, Alfarra MR, Williams PI, Bower K, Kondo Y, Schneider J, Drewnick F, Borrmann S, Weimer S, Demerjian K, Salcedo D, Cottrell L, Griffin R, Takami A, Miyoshi T, Hatakeyama S, Shimono A, Sun JY, Zhang YM, Dzepina K, Kimmel JR, Sueper D, Jayne JT, Herndon SC, Trimborn AM, Williams LR, Wood EC, Middlebrook AM, Kolb CE, Baltensperger U, Worsnop DR. 2009. Evolution of organic aerosols in the atmosphere. Science 326(5959):1525-9.

Kirillova EN, Sheesley RJ, Andersson A, Gustafsson O. 2010. Natural abundance ${ }^{13} \mathrm{C}$ and ${ }^{14} \mathrm{C}$ analysis of water-soluble organic carbon in atmospheric aerosols. Analytical Chemistry 82(19):7973-8.

Lanz VA, Prevot ASH, Alfarra MR, Weimer S, Mohr C, DeCarlo PF, Gianini MFD, Hueglin C, Schneider J, Favez O, D'Anna B, George C, Baltensperger U. 2010. Characterization of aerosol chemical composition with aerosol mass spectrometry in Central Europe: an overview. Atmospheric Chemistry and Physics 10(21): 10,453-71.

Levin I, Naegler T, Kromer B, Diehl M, Francey RJ, Gomez-Pelaez AJ, Steele LP, Wagenbach D, Weller R, Worthy DE. 2010. Observations and modelling of the global distribution and long-term trend of atmospheric ${ }^{14} \mathrm{CO}_{2}$. Tellus B 62(1):26-46.

Lighty JS, Veranth JM, Sarofim AF. 2000. Combustion aerosols: Factors governing their size and composition and implications to human health. Journal of the Air \& Waste Management Association 50(9):1565-618.

Lim S, Lee M, Lee G, Kim S, Yoon S, Kang K. 2012. Ionic and carbonaceous compositions of $\mathrm{PM}_{10}, \mathrm{PM}_{2.5}$ and $\mathrm{PM}_{1.0}$ at Gosan $\mathrm{ABC}$ Superstation and their ratios as source signature. Atmospheric Chemistry and Physics 12(4):2007-24.

Mayol-Bracero OL, Guyon P, Graham B, Roberts G, Andreae MO, Decesari S, Facchini MC, Fuzzi S, Artaxo P. 2002. Water-soluble organic compounds in biomass burning aerosols over Amazonia - 2. Apportionment 


\section{Fossil \& Non-Fossil Sources of Different Carbonaceous Fractions}

of the chemical composition and importance of the polyacidic fraction. Journal of Geophysical ResearchAtmospheres 107(D20):8091, doi:10.1029/ 2001JD000522.

Minguillon MC, Perron N, Querol X, Szidat S, Fahrni SM, Alastuey A, Jimenez JL, Mohr C, Ortega AM, Day DA, Lanz VA, Wacker L, Reche C, Cusack M, Amato F, Kiss G, Hoffer A, Decesari S, Moretti F, Hillamo R, Teinila K, Seco R, Penuelas J, Metzger A, Schallhart S, Muller M, Hansel A, Burkhart JF, Baltensperger U, Prevot ASH. 2011. Fossil versus contemporary sources of fine elemental and organic carbonaceous particulate matter during the DAURE campaign in Northeast Spain. Atmospheric Chemistry and Physics 11(23):12,067-84.

Minguillon MC, Querol X, Baltensperger U, Prevot ASH. 2012. Fine and coarse PM composition and sources in rural and urban sites in Switzerland: local or regional pollution? Science of the Total Environment 427:191-202.

Mohn J, Szidat S, Fellner J, Rechberger H, Quartier R, Buchmann B, Emmenegger L. 2008. Determination of biogenic and fossil $\mathrm{CO}_{2}$ emitted by waste incineration based on ${ }^{14} \mathrm{CO}_{2}$ and mass balances. Bioresource Technology 99(14):6471-9.

Nel A. 2005. Air pollution-related illness: effects of particles. Science 308(5723):804-6.

Pöschl U. 2005. Atmospheric aerosols: composition, transformation, climate and health effects. Angewandte Chemie International Edition 44(46):7520 40.

Ruff M, Wacker L, Gäggeler HW, Suter M, Synal H-A, Szidat S. 2007. A gas ion source for radiocarbon measurements at $200 \mathrm{kV}$. Radiocarbon 49(2):307-14.

Sandradewi J, Prévôt ASH, Szidat S, Perron N, Alfarra MR, Lanz VA, Weingartner E, Baltensperger U. 2008. Using aerosol light absorption measurements for the quantitative determination of wood burning and traffic emission contributions to particulate matter. Environmental Science \& Technology 42(9):3316-23.

Sciare J, d'Argouges O, Sarda-Esteve R, Gaimoz C, Dolgorouky C, Bonnaire N, Favez O, Bonsang B, Gros V. 2011. Large contribution of water-insoluble secondary organic aerosols in the region of Paris (France) during wintertime. Journal of Geophysical Research 116(D22): D22203, doi:10.1029/2011JD015756.

Stuiver M, Polach HA. 1977. Discussion: reporting of ${ }^{14} \mathrm{C}$ data. Radiocarbon 19(3):355-63.

Synal H-A, Stocker M, Suter M. 2007. MICADAS: a new compact radiocarbon AMS system. Nuclear Instruments and Methods in Physics Research B 259(1): $7-13$.

Szidat S, Jenk TM, Gäggeler HW, Synal H-A, Fisseha R, Baltensperger U, Kalberer M, Samburova V, Wacker L, Saurer M, Schwikowski M, Hajdas I. 2004a. Source apportionment of aerosols by ${ }^{14} \mathrm{C}$ measurements in different carbonaceous particle fractions. Radiocarbon 46(1):475-84.
Szidat S, Jenk TM, Gäggeler HW, Synal H-A, Hajdas I, Bonani G, Saurer M. 2004b. THEODORE, a two-step heating system for the $\mathrm{EC} / \mathrm{OC}$ determination of radiocarbon $\left({ }^{14} \mathrm{C}\right)$ in the environment. Nuclear Instruments and Methods in Physics Research B 223-224:829-36.

Szidat S, Jenk TM, Synal H-A, Kalberer M, Wacker L, Hajdas I, Kasper-Giebl A, Baltensperger U. 2006. Contributions of fossil fuel, biomass-burning, and biogenic emissions to carbonaceous aerosols in Zurich as traced by ${ }^{14} \mathrm{C}$. Journal of Geophysical Research 111(D7): D07206, doi:10.1029/2005JD006590.

Szidat S, Prévôt ASH, Sandradewi J, Alfarra MR, Synal HA, Wacker L, Baltensperger U. 2007. Dominant impact of residential wood burning on particulate matter in Alpine valleys during winter. Geophysical Research Letters 34(5): L05820, doi:10.1029/ 2006GL028325.

Szidat S, Ruff M, Perron N, Wacker L, Synal H-A, Hallquist M, Shannigrahi AS, Yttri KE, Dye C, Simpson D. 2009. Fossil and non-fossil sources of organic carbon (OC) and elemental carbon (EC) in Goeteborg, Sweden. Atmospheric Chemistry and Physics 9:152135.

Szidat S, Bench G, Bernardoni V, Calzolai G, Czimczik CI, Derendorp L, Dusek U, Elder K, Fedi M, Genberg J, Gustafsson Ö, Kirillova E, Kondo M, McNichol AP, Perron N, Santos GM, Stenström K, Swietlicki E, Ushida M, Wacker L, Vecchi R, Zhang YL, Prévôt ASH. 2013. Intercomparison of ${ }^{14} \mathrm{C}$ analysis of carbonaceous aerosols: Exercise 2009. Radiocarbon, these proceedings, doi:10.2458/azu_js_rc.55.16314.

Wacker L, Fahrni SM, Hajdas I, Molnar M, Synal HA, Szidat S, Zhang YL. 2013. A versatile gas interface for routine radiocarbon analysis with a gas ion source. Nuclear Instruments and Methods in Physics Research B 294:315-9.

Weber RJ, Sullivan AP, Peltier RE, Russell A, Yan B, Zheng M, de Gouw J, Warneke C, Brock C, Holloway JS, Atlas EL, Edgerton E. 2007. A study of secondary organic aerosol formation in the anthropogenic-influenced southeastern United States. Journal of Geophysical Research 112(D13): D13302, doi:10.1029/ 2007JD008408.

Wozniak AS, Bauer JE, Dickhut RM. 2012. Characteristics of water-soluble organic carbon associated with aerosol particles in the eastern United States. Atmospheric Environment 46:181-8.

Wozniak AS, Bauer JE, Dickhut RM, Xu L, McNichol AP. 2013. Isotopic characterization of aerosol organic carbon components over the eastern United States. Journal of Geophysical Research-Atmospheres 117(D13): D13303, doi:10.1029/2011JD017153.

Zhang YL, Perron N, Ciobanu VG, Zotter P, Minguillon MC, Wacker L, Prevot ASH, Baltensperger U, Szidat S. 2012. On the isolation of OC and EC and the optimal strategy of radiocarbon-based source apportionment of carbonaceous aerosols. Atmospheric Chemistry and Physics 12(22):10,841-56. 